THIRD SERIES • VOLUME $28 \cdot$ PART 2

APRIL 20 I 8

Journal of the

Royal Asiatic

Society

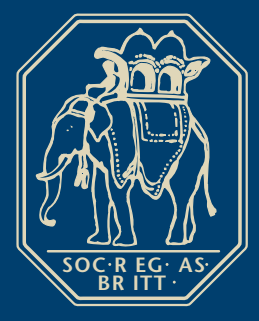

CAMBRIDGE

UNIVERSITY PRESS

Is S N : I $356-I 863$ 
Journal of the Royal Asiatic Society of Great Britain and Ireland

14 Stephenson Way, London NW1 2HD

www.royalasiaticsociety.org

INTERNATIONAL EDITORIAL BOARD

Muzaffar Alam, University of Chicago

Seema Alavi, Jamia Millia Islamia, New Delhi

Azyumardi Azra, Universitas Islam Negeri

Tim Barrett, SOAS, University of London

Jere Bacharach, University of Washington

Edhem Eldem, Bogarici University, Istanbul

Carl Ernst, University of North Carolina

Richard Gombrich, University of Oxford

Andrew Gordon, Harvard University

Edmund Herzig, University of Oxford

Sepp Linhart, University of Vienna
Rana Mitter, University of Oxford

David O. Morgan, University of Wisconsin

Tariq Rahman, Quaid-i Azam University, Islamabad

Anthony Reid, UCL A

Richard G. Salomon, University of Washington

Oktor Skjaervo, Harvard University

Nancy Steinhardt, University of Pennsylvania

Roel Sterckx, University of Cambridge

Wang Gungwu, National University Singapore

Muhammad Q. Zaman, Princeton University

\section{JOURNAL EDITORIAL BOARD}

Professor Peter Robb (President), Professor Sarah Ansari (JRAS Hon. Editor), Dr Gordon Johnson, Professor F. C. R. Robinson, Professor David Morgan, Professor François de Blois, Dr Weipin Tsai, Dr Alison Ohta, Charlotte de Blois.

Journal of the Royal Asiatic Society (ISSN I356-I863) is published for the Royal Asiatic Society in January, April, July and October by Cambridge University Press. The Editor of the Journal invites the submission of original scholarly articles on the anthropology, archaeology, architecture, art, history, languages, literatures, philosophies and religions of all parts of Asia, together with north Africa and Ethiopia. Books sent for review in the Journal cannot be returned. (C) The Royal Asiatic Society 2018

Subscriptions: Journal of the Royal Asiatic Society (ISSN I356-I863) Volume 28, Series I subscription prices (excluding VAT), valid until 3I December 2018, are per volume, £,256 UK and elsewhere (US \$438) for institutions, $£, 57$ (US \$90) for individuals ordering direct from the publisher and certifying that the journal is for their personal use. The electronic-only price available to institutional subscribers is $£ 208$ (US \$353 in USA, Canada and Mexico). Single issues cost £,74 (US \$126). US dollar prices apply to USA, Canada and Mexico. Prices include delivery by air where appropriate. EU subscribers (outside the UK) who are not registered for VAT should add VAT at their country's rate. VAT registered subscribers should provide their VAT registration number. Orders, which must be accompanied by payment, may be sent to a bookseller, subscription agent or to the publishers: Cambridge University Press, Journals Fulfillment Department, UPH, Shaftesbury Road, Cambridge CB2 8BS, UK. or Cambridge University Press, Journals Fulfillment Department, 1 Liberty Plaza, Floor 20, New York, NY 10006, USA . Japanese prices for institutions are available from Kinokuniya Company Ltd, P.O. Box 55, Chitose, Tokyo I56, Japan. Fellows of the The Royal Asiatic Society automatically receive the journal. Information about the Society is found at the end of the Journal.

Back Issues: Back volumes up to and including 1983 are available from Schmidt Periodicals GmbH, Dettendorf, D-820I Bad Feilnbach 2, Germany. Subsequent volumes prior to the present series are available from The Royal Asiatic Society. Back volumes in the present series are available from Cambridge University Press.

Advertising: Apply to Cambridge University Press, UK or North American Branch.

Copying: This journal is registered with the Copyright Clearance Center, 222 Rosewood Drive, Danvers, MA 01923, USA (www.copyright.com). Organizations in the USA who are also registered with CCC may therefore copy material (beyond the limits permitted by sections 107 and 108 of US copyright law) subject to payment to CCC. This consent does not extend to multiple copying for promotional or commercial purposes.

Organisations authorised by the Copyright Licensing Agency may also copy material subject to the usual conditions. ISI Tear Sheet Service, 350I Market Street, Philadelphia, Pennsylvania 19I04, USA, is authorised to supply single copies of separate articles for private use only. For all other use permission must be sought from Cambridge or the North American Branch of Cambridge University Press. 


\section{Journal of the}

\section{Royal Asiatic Society}

THIRD SERIES - VOLUME $28 \cdot$ PART $2 \cdot$ APRIL $20 I 8$

\section{CONTENTS}

Language as Power: Literary Interpretations of the Qur'an in Early Islam.

By Tehseen Thaver

Remembering Saladin: The Crusades and the Politics of Heresy in Persian

Historiography. By Daniel Beben

The Concept of jadhb and the Image of majdhūb in Sufi Teachings and Life in the

Period between the Fourth/Tenth and the Tenth/Sixteenth Centuries.

By Arin Salamah-Qudsi

After the Massacres: Nursing Survivors of Partition Violence in Pakistan Punjab

Camps. By Ilyas Chattha

G.A. Naqvi: from Indian Police (UP), I926 to Pakistani Citizen (Sindh), I947. By Rakesh Ankit

The Last Days of the Song Dynasty: Evidence of the Flight of Song Officials to Southeast Asia before the Mongol Invasions. By Adam T. Kessler

Building a Modern City: Legacies of Residential Development and Architectural Adaptation in Colonial Hong Kong. By Leung Kwok Prudence Lau

Revisiting the Bujang Valley: A Southeast Asian entrepôt complex on the maritime trade route. By Stephen A. Murphy

\section{BOOK REVIEWS}

Trevor H. J. Marchand: Architectural Heritage of Yemen: Buildings That Fill My Eye (Rosalind Wade Haddon)

Anna L. Dallapiccola: The Great Platform at Vijayanagara. Architecture and Sculpture (Richard Blurton)

John McAleer: Picturing India: People, Places, and the World of the East India Company (Tom Young)

Bruno De Nicola: Women in Mongol Iran: The Khātūns (Timothy May)

Martin Kern and Dirk Meyer: Origins of Chinese Political Philosophy: Studies in the Composition and Thought of the Shangshu (Classic of Documents) (Paul R. Goldin)

Hartmut Walravens: Ernst Boerschmann: Pagoden in China, Das unveröffentlichte Werk

"Pagoden II," (Nancy Shatzman Steinhardt) 